\title{
The association of heavy metals concentration in air and health risk assessment in Paka, Malaysia
}

\author{
Siti Noor Syuhada Muhammad Amin a, Azman Azid a, *, Saiful Iskandar Khalit a, Mohd Saiful \\ Samsudin ${ }^{\mathrm{b}}$, Ku Mohd Kalkausar Ku Yusof a \\ a Faculty of Bioresources and Food Industry, Universiti Sultan Zainal Abidin, Besut Campus, 22200 Besut, Terengganu, Malaysia \\ ${ }^{b}$ Dr. F.A.S.Technologies, Blok D1, Tingkat 2, UniSZA Digital Hub, UniSZA Besut Campus, 22200 Besut, Terengganu, Malaysia \\ * Corresponding author: azmanazid@unisza.edu.my
}

\section{Article history}

Received 28 December 2018

Revised 22 February 2019

Accepted 4 April 2019

Published Online 15 May 2019

\begin{abstract}
Heavy metals are classified as the materials that have density five times higher than water. They can be spread in the world through air, water and other routes. In this study, it was focused on heavy metals in air. Paka has be choosen in this study as it is the industrial estate that contributed to air pollution. The aim of this study was to determine an association between heavy metals concentration in air and health risk assessment in Paka, Malaysia. Eight points were selected for this study within two monsoon seasons. The sampling for southwest monsoon was done in August and September 2017 while for northeast monsoon was done in December 2017 and February 2018. The samples were digested by using aqua regia method. The concentration of heavy metals was analysed by using inductively coupled plasma mass spectrometry (ICPMS). For southwest monsoon, the results showed that the concentration of Fe was the highest with the value of mean $\pm S D(0.272 \mathrm{mg} / \mathrm{Kg} \pm$ 0.103 ) and the lowest mean concentration was recorded for $\mathrm{Cu}$ with the value of $0.002 \mathrm{mg} / \mathrm{Kg} \pm$ 0.001 . For northeast monsoon, Fe was recorded the highest concentration of heavy metals and As was the lowest with the value $0.125 \mathrm{mg} / \mathrm{Kg} \pm 0.041$ and $0.002 \mathrm{mg} / \mathrm{Kg} \pm 0.001$, respectively. The health risk assessment indicated no risks from these metals as the HQs and Hls of six metals were almost all lower than the safe level $(=1)$ for the industrial workers. The $\mathrm{HI}$ values were decreased in the order of $\mathrm{Fe}>\mathrm{Cd}>\mathrm{Pb}>\mathrm{As}>\mathrm{Zn}>\mathrm{Cu}$. Fe and $\mathrm{Cd}$ showed higher values close to safe level, while $\mathrm{Zn}$ and $\mathrm{Cu}$ were lowest. It could be concluded that the industrial emission was the major source of heavy metals in the atmosphere along Paka industrial area. The human health risk assessment has proved to be a powerful tool to distinguish heavy metals and exposure routes of most concerns in urban environments to estimate the risk of mix metal contaminates.
\end{abstract}

Keywords: Heavy metals, health risk, Paka, ICPMS

(C) 2019 Penerbit UTM Press. All rights reserved

\section{INTRODUCTION}

Air pollution is the presence of a pollutant in the air. It can be toxic and harmful to living things in the polluted environment. Since they cannot be destructed, heavy metals can be classified as natural environmental contaminants. Heavy metals are considered as toxic for human health if they accumulate in high concentrations. The presented heavy metals in air will cause and lead to major problems for human health (Lee et al. 2006; Gbadebo and Bankole, 2007; Ripin et al. 2014). There are three routes of heavy metals exposure to human. The stated three routes are inhalation, ingestion and skin contact. The higher concentrations of trace elements in atmospheric particles are associated with health's effect on human. They will damage the cells of the body especially in respiratory system, cardiovascular problems, premature mortality and other bad impacts (Prieditis and Adamson, 2002; Magas et al., 2007; Callen et al., 2009; Wild et al., 2009; Lippmann, 2009).

Determination of heavy metals concentration from the dust in the atmosphere is a great important planning for strategic management. The information regarding to the quality of atmospheric dust in Paka Industrial Area, Malaysia is still not discovered yet by other researchers. The aim of this study was to determine the concentrations of heavy metals ( $\mathrm{As}, \mathrm{Cd}, \mathrm{Cu}, \mathrm{Fe}, \mathrm{Pb}$ and $\mathrm{Zn}$ ) in atmospheric dust as well as their associations towards industrial workers's health risk of Paka Industrial Area, Malaysia. These heavy metals have been selected due to emission from the traffic and routine industrial activities that led to production of these heavy metals into the atmosphere and directly affected the human health (Aksu, 2015).

\section{EXPERIMENTAL}

\section{Sample collection and digestion}

The samples were taken in 2-days per each point in the Paka industrial area. The samples were collected in 7 months from August 2017 until February 2018. Each area was consisted of eight points. The process of sampling was 8-hours for each point. Air sampling was carried out using filter paper and placed in air. Air sampler was placed at $1.5 \mathrm{~m}$ platform due to this high be sufficient to human breath level. The loaded filters were removed from the air sampler and placed in the cleaned plastic bag after the sampling process. An electronic balance was used to determine the mass of the particles collected on each filter paper. The weights before and after sampling were measured respectively and the differences were recorded. The samples were digested by using aqua regia method. Aqua regia 
method is the mixture of nitric acid and hydrochloric acid. This digestion process is used in general, to determine the contents of heavy metals in the environment (Soon and Abboud, 1993; Taraškevičius et al., 2012).

Table 1 Exposure factors for dose models.

\begin{tabular}{|c|c|c|c|c|}
\hline Factor & Definition & Unit & Value & Reference \\
\hline & & & \multicolumn{2}{|l|}{ Adult } \\
\hline C & Dust's heavy metal concentrations & $\mathrm{mg} / \mathrm{kg}$ & & This study \\
\hline $\operatorname{lng} R$ & Ingestion rate of soil & $\mathrm{mg} /$ day & 100 & (USEPA, 1989) \\
\hline EF & Frequency of exposure & days/year & 350 & USEPA, 1997) \\
\hline ED & Duration of exposure & years & 24 & USEPA, 2001) \\
\hline BW & Average body weight & $\mathrm{kg}$ & 55.9 & USEPA, 1997) \\
\hline AT & Average of time & days & $365 \times$ ED & (USEPA, 1989) \\
\hline CF & Conversion factor & $\mathrm{kg} / \mathrm{mg}$ & $1 \times 10^{-6}$ & \\
\hline $\operatorname{lnh} R$ & Inhalation rate & $\mathrm{m}^{3} /$ day & 20 & USEPA, 1997) \\
\hline PEF & Particle emission factor & $\mathrm{m}^{3} / \mathrm{kg}$ & $1.32 \times 10^{9}$ & USEPA, 1997) \\
\hline SA & Surface area of the skin & $\mathrm{cm}^{2}$ & 5000 & USEPA, 1997) \\
\hline SL & Adherence factor of skin for dust & $\mathrm{mg} / \mathrm{cm}^{2}$ & 1 & USEPA, 1997) \\
\hline ABS & Factor for dermal absorption & & 0.001 & USEPA, 1997) \\
\hline
\end{tabular}

\section{Data analysis}

The concentrations of elements were measured by using ICPMS. The calibration was done and each element has been recorded in the instrument using the blank solutions. After the process of calibration, all samples were analysed and the data was recorded. The data was analysed using XLSTAT version 2017.

\section{Health risk assessment}

\section{Exposure dose}

$$
\begin{aligned}
& D_{\text {Ing }}=\frac{C x_{\text {Ing } R \times E F \times E D \times C F}}{B W \times A T} \\
& D_{\text {Inh }}=\frac{C \times \operatorname{Inh} R \times E F \times E D}{P E F \times B W \times A T} \\
& D_{D e r}=\frac{C \times S L \times S A \times A B S \times E F \times E D \times C F}{B W \times A T} \\
& H Q=\frac{D}{R f D}
\end{aligned}
$$$$
H I=\sum_{i=1}^{3} H Q i
$$

$D_{\text {Ing }}$ is daily exposure amount of metals through ingestion $(\mathrm{mg} / \mathrm{kg} /$ day); DInh is daily exposure amount of metals through inhalation $(\mathrm{mg} / \mathrm{kg} / \mathrm{day})$; DDerm is daily exposure amount of metals through dermal contact $(\mathrm{mg} / \mathrm{kg} / \mathrm{day})$. The exposure factors for these models were showed in Table 1 with the reference of USEPA and environmental site assessment guideline 2009.

The reference dose (RfD) was referred to an estimation of maximum permissible risk on human population through daily exposure by taking into consideration of sensitive group during a lifetime. If an average daily dose (D) value was lower than the reference dose, it was indicated that there would be not any adverse health effect; otherwise if the $\mathrm{D}$ value was higher than the RfD, it was is likely that the exposure pathway would cause adverse human health effect (USEPA, 2001) (Table 2 and Table 3). When HQ $\leq 1$ indicated to no adverse health effects and $\mathrm{HQ}>1$ indicated to likely adverse health effects (USEPA, 1997). The HQs could be added and generated a Hazard Index (HI) to estimate the risk of mix metal contaminates (Table 4).

Hazard Index (HI) was referred to the sum of more than one Hazard Quotient for multiple substances or multiple exposure pathways of the population (USEPA, 1989). HI was equal to the sum of $\mathrm{HQ}$. If the value of $\mathrm{HI} \leq 1$, it was believed that there was no significant risk of health effects. If $\mathrm{HI}>1$, it was meant that there was a great chance of health effects. The probability of health effects was increased with the increasing value of HI (USEPA, 1989).

\section{RESULTS AND DISCUSSION}

\section{The association of heavy metals concentration and health risk}

Based on the finding, for southwest monsoon, the results showed that the concentration of $\mathrm{Fe}$ was the highest with the value of mean $\pm \mathrm{SD}(0.272 \mathrm{mg} / \mathrm{Kg} \pm 0.103)$ and the lowest mean concentration was recorded for $\mathrm{Cu}$ with the value of $0.002 \mathrm{mg} / \mathrm{Kg} \pm 0.001$. For northeast monsoon, $\mathrm{Fe}$ was recorded the highest concentration of heavy metals and As was the lowest with the value of $0.125 \mathrm{mg} / \mathrm{Kg} \pm$ 0.041 and $0.002 \mathrm{mg} / \mathrm{Kg} \pm 0.001$, respectively.

The mean (SD) for concentration's level showed that the heavy metals have significant different $(p<0.05)$ between the sampling stations. Several studies have suggested that the reacted heavy metals such as $\mathrm{Pb}, \mathrm{Cd}$ and As to the reactive oxygen species (ROS) might lead to toxicity to the public health (Tchounwou et al., 2001; Tchounwou et al., 2004a; Tchounwou et al., 2004b; Yedjou and Tchounwou, 2006; Yedjou and Tchounwou, 2007; Yedjou and Tchounwou, 2008). These reactive and oxidised metals might induce multiple organ damage, even at lower levels of exposure (Tchounwou et al., 2012). Based on this study, the mean concentration values of $\mathrm{Pb}, \mathrm{Cd}$ and $\mathrm{As}$ were much higher than the target value by European Commission in Directive 2004/107/EC and Directive 2008/50/EC. The accumulation of heavy metals in higher concentration might contribute to health effects while in sufficient range, it might be considered as essential for human body.

The concentrations level of heavy metals in Paka were recorded highest in $\mathrm{Fe}$ and the lowest in $\mathrm{Cu}$. The finding of this research was also in line with the current literature which stated that Fe was the highest traces element in the study area (Azid et al., 2018).

In this study, HI was used to assess human health risk of metal exposure to dusts in the industrial area. The HQs and HIs of six metals were almost all lower than the safe level $(=1)$. These results indicated that there was no risk from these metals towards health. On the whole, $\mathrm{HI}$ value was decreased in the order of $\mathrm{Fe}>\mathrm{Cd}>\mathrm{Pb}>\mathrm{As}>\mathrm{Zn}>\mathrm{Cu}$. $\mathrm{Fe}$ and $\mathrm{Cd}$ exhibited higher values close to the safe level, while $\mathrm{Zn}$ and $\mathrm{Cu}$ were lowest. The values of health risk obtained in this study were in the receivable range, although some assumptions applied in the models were seemed to be ideal and simple. The results reflected that exposure to heavy metals in dusts solely would not cause serious health impacts in the study. However, the calculated risk was affected by a high degree of uncertainty. Despite of many uncertainties, health risk assessment of human has proved to be a powerful medium to distinguish heavy metals and exposure pathways of most concerns in urban environments. Dust toxics risk assessment program could demonstrate the value of a risk-oriented approach to inform residents/government about the potential risks associated with exposure to metals (Shi et al., 2011; Wahab et al., 2012; Abdullah and Alias, 2018). 
Table 2 Total concentrations level of heavy metals for Paka (Southwest Monsoon) in three models.

\begin{tabular}{|c|c|c|c|c|c|}
\hline $\begin{array}{l}\text { Heavy } \\
\text { metals }\end{array}$ & $\begin{array}{c}\text { Statistical } \\
\text { analysis }\end{array}$ & $\begin{array}{l}\text { Concentrations } \\
\text { level (mg/L) }\end{array}$ & $D_{\text {Ing }}(m g /(k g . d))$ & $D_{\operatorname{lnh}}(\mathrm{mg} /(\mathbf{k g} \cdot \mathrm{d}))$ & $D_{\text {Derm }}(\mathrm{mg} /(\mathrm{kg} \cdot \mathrm{d}))$ \\
\hline \multirow[t]{4}{*}{$\mathrm{Fe}$} & Mean & 0.272 & $4.66 \mathrm{E}-07$ & $7.06 \mathrm{E}-11$ & $2.33 E-08$ \\
\hline & Min & 0.130 & 2.21E-07 & $3.35 \mathrm{E}-11$ & 1.11E-08 \\
\hline & Max & 0.473 & $8.12 \mathrm{E}-07$ & $1.23 \mathrm{E}-10$ & $4.06 \mathrm{E}-08$ \\
\hline & SD & 0.103 & & & \\
\hline \multirow[t]{4}{*}{$\mathrm{Cu}$} & Mean & 0.002 & 3.09E-09 & $4.68 \mathrm{E}-13$ & $1.54 \mathrm{E}-10$ \\
\hline & Min & 0.001 & 1.20E-09 & $1.82 \mathrm{E}-13$ & $6.00 \mathrm{E}-11$ \\
\hline & Max & 0.006 & $9.78 \mathrm{E}-09$ & $1.48 \mathrm{E}-12$ & $4.89 \mathrm{E}-10$ \\
\hline & SD & 0.001 & & & \\
\hline \multirow[t]{4}{*}{$\mathrm{Pb}$} & Mean & 0.107 & 1.83E-07 & $2.78 \mathrm{E}-11$ & $9.17 \mathrm{E}-09$ \\
\hline & Min & 0.004 & 7.38E-09 & $1.12 \mathrm{E}-12$ & $3.69 \mathrm{E}-10$ \\
\hline & $\operatorname{Max}$ & 0.463 & 7.94E-07 & $1.20 \mathrm{E}-10$ & $3.97 \mathrm{E}-08$ \\
\hline & SD & 0.156 & & & \\
\hline \multirow[t]{4}{*}{$\mathrm{Cd}$} & Mean & 0.010 & 1.70E-08 & $2.57 \mathrm{E}-12$ & $8.49 \mathrm{E}-10$ \\
\hline & Min & 0.001 & 1.72E-09 & $2.60 \mathrm{E}-13$ & $8.58 \mathrm{E}-11$ \\
\hline & Max & 0.031 & 5.32E-08 & 8.06E-12 & 2.66E-09 \\
\hline & SD & 0.010 & & & \\
\hline \multirow[t]{4}{*}{ As } & Mean & 0.005 & 8.23E-09 & $1.25 \mathrm{E}-12$ & 4.12E-10 \\
\hline & Min & 0.003 & 5.15E-09 & $7.80 \mathrm{E}-13$ & $2.57 \mathrm{E}-10$ \\
\hline & Max & 0.006 & $1.03 \mathrm{E}-08$ & $1.56 \mathrm{E}-12$ & $5.15 \mathrm{E}-10$ \\
\hline & SD & 0.001 & & & \\
\hline \multirow[t]{4}{*}{$\mathrm{Zn}$} & Mean & 0.104 & $1.78 \mathrm{E}-07$ & $2.69 \mathrm{E}-11$ & 8.89E-09 \\
\hline & Min & 0.010 & 1.72E-08 & $2.60 \mathrm{E}-12$ & $8.58 \mathrm{E}-10$ \\
\hline & Max & 0.347 & 5.95E-07 & $9.01 \mathrm{E}-11$ & $2.97 \mathrm{E}-08$ \\
\hline & SD & 0.114 & & & \\
\hline
\end{tabular}

Table 3 Total concentrations level of heavy metals for Paka (Northeast Monsoon) in three models.

\begin{tabular}{|c|c|c|c|c|c|}
\hline $\begin{array}{l}\text { Heavy } \\
\text { metals }\end{array}$ & $\begin{array}{c}\text { Statistical } \\
\text { analysis }\end{array}$ & $\begin{array}{c}\text { Concentrations } \\
\text { Level (mg/L) }\end{array}$ & $D_{\text {lng }}(\mathrm{mg} /(\mathrm{kg} . \mathrm{d}))$ & $D_{\operatorname{lnh}}(\mathrm{mg} /(\mathrm{kg} \cdot \mathrm{d}))$ & $D_{\text {Derm }}(\mathrm{mg} /(\mathrm{kg} \cdot \mathrm{d}))$ \\
\hline \multirow[t]{4}{*}{$\mathrm{Fe}$} & Mean & 0.125 & $2.14 \mathrm{E}-07$ & $3.24 \mathrm{E}-11$ & $1.07 \mathrm{E}-08$ \\
\hline & Min & 0.087 & 1.49E-07 & $2.25 \mathrm{E}-11$ & 7.44E-09 \\
\hline & Max & 0.200 & $3.43 \mathrm{E}-07$ & $5.20 \mathrm{E}-11$ & $1.72 \mathrm{E}-08$ \\
\hline & SD & 0.041 & & & \\
\hline \multirow[t]{4}{*}{$\mathrm{Cu}$} & Mean & 0.002 & 3.26E-09 & $4.94 \mathrm{E}-13$ & $1.63 \mathrm{E}-10$ \\
\hline & Min & 0.000 & $0.00 \mathrm{E}+00$ & $0.00 \mathrm{E}+00$ & $0.00 \mathrm{E}+00$ \\
\hline & Max & 0.004 & 6.86E-09 & $1.04 \mathrm{E}-12$ & $3.43 E-10$ \\
\hline & SD & 0.001 & & & \\
\hline \multirow[t]{4}{*}{$\mathrm{Pb}$} & Mean & 0.107 & 1.84E-07 & $2.78 \mathrm{E}-11$ & $9.18 \mathrm{E}-09$ \\
\hline & Min & 0.003 & $5.15 \mathrm{E}-09$ & $7.80 \mathrm{E}-13$ & $2.57 \mathrm{E}-10$ \\
\hline & Max & 0.444 & $7.62 \mathrm{E}-07$ & $1.15 \mathrm{E}-10$ & 3.81E-08 \\
\hline & SD & 0.161 & & & \\
\hline \multirow[t]{4}{*}{$\mathrm{Cd}$} & Mean & 0.005 & 8.58E-09 & $1.30 \mathrm{E}-12$ & $4.29 \mathrm{E}-10$ \\
\hline & Min & 0.000 & $1.72 \mathrm{E}-10$ & $2.60 \mathrm{E}-14$ & $8.58 \mathrm{E}-12$ \\
\hline & Max & 0.012 & 2.06E-08 & $3.12 \mathrm{E}-12$ & 1.03E-09 \\
\hline & SD & 0.004 & & & \\
\hline \multirow[t]{4}{*}{ As } & Mean & 0.001 & 1.89E-09 & $2.86 \mathrm{E}-13$ & $9.43 \mathrm{E}-11$ \\
\hline & Min & 0.000 & $0.00 \mathrm{E}+00$ & $0.00 \mathrm{E}+00$ & $0.00 \mathrm{E}+00$ \\
\hline & Max & 0.002 & 3.43E-09 & $5.20 \mathrm{E}-13$ & $1.72 \mathrm{E}-10$ \\
\hline & SD & 0.001 & & & \\
\hline \multirow[t]{4}{*}{$\mathrm{Zn}$} & Mean & 0.053 & $9.02 \mathrm{E}-08$ & $1.37 \mathrm{E}-11$ & 4.51E-09 \\
\hline & Min & 0.000 & $0.00 \mathrm{E}+00$ & $0.00 \mathrm{E}+00$ & $0.00 \mathrm{E}+00$ \\
\hline & Max & 0.183 & $3.14 \mathrm{E}-07$ & $4.76 \mathrm{E}-11$ & 1.57E-08 \\
\hline & SD & 0.044 & & & \\
\hline
\end{tabular}

Table 4 Health risk from heavy metals in air of Paka.

\begin{tabular}{cccccc}
\hline $\begin{array}{c}\text { Types of } \\
\text { monsoon }\end{array}$ & $\begin{array}{c}\text { Heavy } \\
\text { metals }\end{array}$ & $\mathbf{H Q}_{\mathbf{l n g}}$ & $\mathbf{H Q}_{\mathbf{l n h}}$ & $\mathbf{H Q}_{\text {Derm }}$ & $\mathbf{H I}$ \\
\hline Southwest & $\mathrm{Fe}$ & $1.73 \mathrm{E}-03$ & $3.48 \mathrm{E}-09$ & $2.33 \mathrm{E}-05$ & $1.75 \mathrm{E}-03$ \\
& $\mathrm{Cu}$ & $8.35 \mathrm{E}-08$ & $1.16 \mathrm{E}-11$ & $8.11 \mathrm{E}-08$ & $1.65 \mathrm{E}-07$ \\
& $\mathrm{~Pb}$ & $5.23 \mathrm{E}-05$ & $7.90 \mathrm{E}-09$ & $1.75 \mathrm{E}-05$ & $6.98 \mathrm{E}-05$ \\
& $\mathrm{Cd}$ & $1.70 \mathrm{E}-05$ & $2.57 \mathrm{E}-09$ & $1.70 \mathrm{E}-05$ & $3.40 \mathrm{E}-05$ \\
& $\mathrm{As}$ & $5.88 \mathrm{E}-06$ & $7.35 \mathrm{E}-10$ & $1.00 \mathrm{E}-06$ & $6.88 \mathrm{E}-06$ \\
& $\mathrm{Zn}$ & $5.93 \mathrm{E}-07$ & $8.97 \mathrm{E}-11$ & $1.48 \mathrm{E}-07$ & $7.42 \mathrm{E}-07$ \\
\hline Northeast & $\mathrm{Fe}$ & $7.93 \mathrm{E}-04$ & $1.60 \mathrm{E}-09$ & $1.07 \mathrm{E}-05$ & $8.03 \mathrm{E}-04$ \\
& $\mathrm{Cu}$ & $8.81 \mathrm{E}-08$ & $1.23 \mathrm{E}-11$ & $8.58 \mathrm{E}-08$ & $1.74 \mathrm{E}-07$ \\
& $\mathrm{~Pb}$ & $5.26 \mathrm{E}-05$ & $7.90 \mathrm{E}-09$ & $1.75 \mathrm{E}-05$ & $7.01 \mathrm{E}-05$ \\
& $\mathrm{Cd}$ & $8.58 \mathrm{E}-06$ & $1.30 \mathrm{E}-09$ & $8.58 \mathrm{E}-06$ & $1.72 \mathrm{E}-05$ \\
& $\mathrm{As}$ & $1.35 \mathrm{E}-06$ & $1.68 \mathrm{E}-10$ & $2.30 \mathrm{E}-07$ & $1.58 \mathrm{E}-06$ \\
& $\mathrm{Zn}$ & $3.01 \mathrm{E}-07$ & $4.57 \mathrm{E}-11$ & $7.52 \mathrm{E}-08$ & $3.76 \mathrm{E}-07$ \\
\hline
\end{tabular}




\section{CONCLUSION}

This research could provide some beneficial impacts on information about the concentrations level of heavy metals on $\mathrm{Pb}, \mathrm{Cd}$, $\mathrm{Fe}, \mathrm{Cu}, \mathrm{As}$ and $\mathrm{Zn}$ in air from Paka industrial area. As was recorded to be the lowest in Northeast monsoon whereas $\mathrm{Cu}$ for southwest monsoon. The industrial workers were presented to air pollutant (heavy metals) through these three pathways (ingestion, dermal contact and inhalation). The main exposure pathway of heavy metals in this study was ingestion. The estimations of HQ for those pathways of this study were decreased in the order of ingestion $>$ dermal contact $>$ inhalation.

$\mathrm{HI}$ value of $\mathrm{Fe}$ was recorded to be the highest in both monsoons. The other values of $\mathrm{HI}$ were indicated that health risk values obtained for selected metals in air from Paka industrial area were still in the safety range. The metals information from this study would help the suitable parties in reviewing current rules and imposing more strategic planning in handling the pollutants emission into the ambient in order to understand potential environmental health hazard.

\section{ACKNOWLEDGEMENT}

This project was financially supported by University Research Fund (Grant No.: UniSZA/2016/DPU/01). The authors were fully acknowledged Universiti Sultan Zainal Abidin for fund approval and those who were directly or indirectly involved.

\section{REFERENCES}

Abdullah, M. Z., Alias, N. A. 2018. Variation of $\mathrm{PM}_{10}$ and heavy metals concentration of sub-urban area caused by haze episode. Malaysian Journal of Analytical Sciences, 22 (3), 508 - 513.

Aksu, A. 2015. Source of metal pollution in the urban atmosphere (A case study: Tuzla, Istabul). Journal of Environmental Health Science and Engineering, 13, 79.

Azid, A., Muhammad Amin, S. N. S., Khalit, S. I., Ismail, S., Samsudin, M. S., Ku Yusof, K. M. K., Amran, M. A., Yunus, K., Mohd Saudi, A. S. 2018. Determination of selected heavy metals in airborne particles in industrial area: A baseline study. Malaysian Journal of Fundamental and Applied Sciences, 14 (2), 251 - 256.

Callen, M. S., de la Cruz, M. T., Lopez, J. M., Navarro, M. V., Mastral, A. M. 2009. Comparison of receptor models for source apportionment of the PM10 in Zaragoza (Spain). Chemosphere, 76, 1120 - 1129.

Gbadebo, A. M., Bankole, O. D. 2007. Analysis of potentially toxic metals in airborne cement dust around Sagamu South Western Nigeria. Journal of Applied Science, 7, $35-40$.

Lee, C. S., Li, X., Shi, W., Cheung, S. C., Thornton, I. 2006. Metal contamination in urban, suburban and country park soils of Hong Kong: A study based on GIS and multivariate statistics. Science of the Total Environment, 356, $45-61$.

Lippmann, M. 2009. Environmental toxicants: Human exposures and their health effects, Third Edition. John Wiley \& Sons, Inc, Hobokan, NJ.

Magas, O. K., Gunter, J. T., Regens, J. L. 2007. Ambient air pollution and daily pediatric hospitalizations for asthma. Environmental Science and Pollution Research, 14, 19-23.

Prieditis, H., Adamson, I. Y. R. 2002. Comparative pulmonary toxicity of various soluble metals found in urban particulate dusts. Experimental Lung Research, 28, $563-576$.
Ripin, S. N. M., Hasan, S., Kamal, M. L., Hashim, N. M. 2014. Analysis and pollution assessment of heavy metal in soil, Perlis. Malaysian Journal of Analytical Sciences, 18 (1), 155 - 161.

Shi, G. T., Chen, Z. L., Bi, C. J., Wang, L., Teng, J. Y., Li, Y. S., Xu, S.Y. 2011. A comparative study of health risk of potentially toxic metals in urban and suburban road dust in the most populated city of China. Atmospheric Environment, 45, $764-771$

Soon, Y. K., Abboud, S. 1993. Cadmium, chromium, nickel. In M.R. Carter (Ed). Soil Sampling and Methods of Analysis. Lewis, Boca Raton, Fla, USA, pp. 101-108.

Taraškevičius, R., Zinkutè, R., Stakènienè, R., Radavičius, M. 2012. Case study of the relationship between aqua regia and real total contents of harmful trace elements in some European soils. Journal of Chemistry, 2013, Article ID 678140, 15 pp.

Tchounwou P. B., Ishaque, A., Schneider, J. 2001. Cytotoxicity and transcriptional activation of stress genes in human liver carcinoma cells (HepG2) exposed to cadmium chloride. Molecular and Cellular Biochemistry, 222, $21-28$.

Tchounwou, P. B., Centeno J. A., Patlolla A. K. 2004a. Arsenic toxicity, mutagenesis and carcinogenesis - A health risk assessment and management approach. Molecular and Cellular Biochemistry, 255, 47-55.

Tchounwou, P. B., Yedjou, C. G., Foxx, D., Ishaque, A., Shen, E. 2004b. Leadinduced cytotoxicity and transcriptional activation of stress genes in human liver carcinoma cells (HepG2). Molecular and Cellular Biochemistry, 255, $161-170$.

Tchounwou, P. B., Yedjou, C. G., Patlolla, A. K., and Sutton, D. J. 2012. Heavy metal toxicity and the environment. In: Luch, A. (Ed.). Molecular, clinical and environmental toxicology. Basel, Springer, pp. 133-164.

Wild, P., Bourgkard, E., Paris, C. 2009. Lung cancer and exposure to metals: The epidemiological evidence. Methods in Molecular Biology, 472, 139 167.

US EPA (United States Environmental Protection Agency). 1989. Risk assessment guidance for superfund, Volume I: Human Health Evaluation Manual (Part A). EPA/540/1-89/002. Washington, D. C.: Office of Emergency and Remedial Response, US Environmental Protection Agency.

US EPA (United States Environmental Protection Agency). 1997. Exposure factors handbook. EPA/600/P-95/002F (Final Report). Washington, D. C.: Office of Research and Developmental, National Center for Environmental Assessment, Environmental Protection Agency.

US EPA (United States Environmental Protection Agency). 2001. Risk Assessment guidance for superfund: Volume III - Part A, Process for conducting probabilistic risk assessment. EPA 540-R-02-002. Washington, D. C.: Office of Emergency and Remedial Response, US Environmental Protection Agency.

Wahab, N. A. A., Darus, F. M., Isa, N., Sumari, S. M., Hanafi, N. F. M. 2012. Heavy metal concentration of settled surface dust in residential building. Malaysian Journal of Analytical Sciences, 16 (1), 18 - 23.

Yedjou, C. G., Tchounwou P. B. 2006. Oxidative stress in human leukemia cells (HL-60), human liver carcinoma cells (HepG2) and human Jerkat-T cells exposed to arsenic trioxide. Metal Ions in Biology Medicine, 9, 298 303.

Yedjou, G. C., Tchounwou, P. B. 2007. In vitro cytotoxic and genotoxic effects of arsenic trioxide on human leukemia cells using the MTT and alkaline single cell gel electrophoresis (comet) assays. Molecular and Cellular Biochemistry, 301, 123 - 130.

Yedjou, G. C., Tchounwou, P. B. 2008. N-acetyl-cysteine affords protection against lead-induced cytotoxicity and oxidative stress in human liver carcinoma (HepG2) cells. International Journal of Environmental Research and Public Health, 4(2), 132 - 137. 